\section{MITCHINER MEMORIAL LECTURE}

\section{WELLINGTON, NAPOLEON AND THE MEDICAL SERVICES}

Maj Gen F M Richardson, CB, DSO, OBE, MD, L/RAMC

The first time I sounded off in this lecture theatre was on the Great Highland Bagpipe, when I played 'The Lament for the Children' to the Scottish naturalist Seton Gordon, but have no fear - I'm past all that now accordingly, at my age, I felt particularly flattered by the honour of being invited to give this Memorial Lecture. I know that I am not qualified, like my predecessors, to speak of Philip Mitchiner's place as a surgeon, a teacher and administrator, but I soon overcame the feeling of unworthiness when I refiected that I am one of the few who can remember our famous Territorial medical Major General as a mere Lieutenant Colonel, commanding the London University OTC. ${ }^{*}$ When we camped alongside them in 1923 the Edinburgh Medical Unit had just been put into the kilt - an obviously inappropriate garb for stretcher drill -involving as it did, what Queen Victoria might have called "fleeting glimpses of Highland scenery" - but it certainly smartened us up, the kilt-wearer must at least keep his knees straight. The London cadets reacted to our Scottish smartness by deliberately making a fool of their drill; for example, on the command 'Stand Easy' they all dipped their knees in the maner of a stage policeman irresistably comic, but it did not amuse 'Mitch' - who harangued them, saying that he would not have his unit outshone in drill or anything by "a bunch of barebottomed barbarians from the North". Well, for this barbarian 61 years later, apart from one close personal friend, my abiding memory is of that memorable figure, spectacles glinting and a bristly convict crop seeming to emphasise the roundness of a rather small head. It has been said that an outstanding appearance is an asset to a military leader and we all know that Philip Mitchiner became just that. In 'Who's Who' his only recreations were given as "University Training Corps and the TA". Last year Professor Cecil Gray spoke of "this devotion to things military in one who himself was so unmilitary". 1 Today I want to suggest that perhaps Mitch's 'devotion' was really to that best of all patients, the British Soldier.

Are any of us really devoted to 'The Army'?, I have often put that question to military audiences. Of course we love our Corps, our Regiment, our comrades; but 'The Army' embraces so much else. For example The War Office (as we used to call it in the days when we were allowed to think of more than mere defence), them, in fact they, whose ideas so often did not seem to Army -Robert Spicer, Philip Wood and John Watts. agree with what we thought was best for us, our unit and our men. When the suspicion steals into the mind that $\varrho$ 'The Army' may not be the most generous and 0 warmhearted of employers, what then keeps us going? It is our love for the British Soldier - the Jock, the Jawan? - when we were so blessed as to have our great Indian $\overrightarrow{\vec{F}}$ Army - That's what keeps us going; and I do not think $\overrightarrow{0}$ that a man can be a really good military leader who does $\underline{ }$ not feel this deep affection.

How do the two great generals of whom I am going to speak, measure up to this criterion? Well, an opinion poll in this country would probably illustrate a curious $\$$ national trait satirised by WS Gilbert, when he put upon $\vec{\circ}$ Ko-Ko's 'little list':

\section{The idiot who praises with extravagant tone}

All centuries but this and every country but his own.

Napoleon, we are accustomed to being told, loved his ? men and made proper provision for those who were sick $\vec{\omega}$ and wounded. Wellington, cold and haughty, called his $\overrightarrow{0}$ men 'the scum of the earth, enlisted for drink', which far too many of them were, and did not support his doctons $N$ in their efforts to do what they could for the casualties? $\stackrel{?}{+}$ 을

These two pictures are diametrically opposite to the truth - damned lies which I shall now nail to the wall, the hope that none of you will ever allow them to ge uncontradicted.

To start with Napoleon and first a few, perhaps les important, misconceptions.

He was not a very small man, $5 \mathrm{ft} 6$ inches and 22/45thơ of an inch accurately measured at the post mortem which was one inch taller than the average Frenchman his day, one and a half inches shorter than the average Englishman $^{3}$ and only three inches shorter than Wellington. The misconception arose from mis- $\stackrel{\mathbb{D}}{\varrho}$ translation of the pied de roi into the pied anglais.

He did not hate the English so much as admire them, "If I had had an English army I would have conquered the Universe" he said. He saw our soldiers as "lions led by donkeys'. He probably esteemed the Scots more highly than the English, but I won't skate on that rather thin ice today. Whatever all those ridiculous advertisements would have us believe, Napoleon very seldom drank brandy, an occasional medicinal sip from a silver flask carried by his Mameluke Roustam Raza.

He was not a great lover (and I believe, never a father) plagued as he was by impotence, infantile external genital organs and an androgynous body, finally becoming embarrassingly less andro- and more-gynous. (After the publication of my first book ${ }^{4}$ an old friend, ex Grenadier Guards, wrote to tell me that, as a director of $\frac{D}{2}$ Christies, he had sold Napoleon's private parts for $£ 18,000$ (catalogue of the sale on $29 \times 69$ ). Later the $N$ English novelist Cecil Roberts, gave me the address of a museum in Rome where Napoleon's foreskin is to be 0 seen in a glass case. I would refer you to my latest book $\mathrm{c}$ 
for the whole astounding story ${ }^{5}$. It is all true! and one's disgust at such desecration of the Imperial corpse can only be intensified by thoughts of the cupidity which led to the sale of the loot in two lots).

Finally, a stupid belief which I have met among quite intelligent people, is that he rose from the ranks, having been, like Hitler, a corporal. Of course his nickname 'The Little Corporal' was, like Marlborough's 'Corporal John', a mark of the affection of their soldiers, which Marlborough richly deserved; whilst Napoleon did not, as I shall show. Such a nickname would have been unthinkable for Wellington, 'Old Nosey' - 'The Peer', he had their complete trust if not, one has to believe, their love.

(The soldiers gave their affection to the quiet, undemonstrative Scotsman, John Moore and the kindly prematurely bald 'Daddy' Hill, but no soldier could compete with the emotional lovable Horatio Nelson.)

Reading of Nelson's death for the umpteenth time, I once had to hide my tears from my family on a holiday beach; but I have often said, and will repeat, that if Nelson had had the misfortune to survive Trafalgar and Wellington the luck to fall at Waterloo, it would be our Army's hero who would be standing up there among the pigeons in Waterloo Square. People knelt in the shingle to touch Nelson's clothing as he left the shores of England for the last time. He loved it, Wellington would have hated it. When the Prince Regent tried to praise him at his own dinner table, Wellington rose abruptly and called for coffee.

Napoleon, to whom his soldiers were merely the tools of his megalo-maniac ambition, could make them believe that he loved them and knew each man. He had some well-rehearsed tricks to convince them of this. I am not criticising him for these tricks. He was more than just a general, having made himself an emperor with millions of subjects. Wellington knew about the tricks to which he himself would not have stooped; but there was one Napoleonic device in leadership which he could, with advantage, have adopted - the use of words, words which Napoleon said, must be as music which speaks to the soul. How well he spoke to the souls of French soldiers. It is a privilege of French officers to address their soldiers as "Mes enfants". Napoleon did not need to and always began with the word "Soldats"! For twenty years, to be one of his soldiers was to be the greatest thing on earth in the most gorgebus uniforms of all time. Poor Michel Ney - le Rougeaud - a clear case of Battle Exhaustion from 1812 to his end, promised to bring 'The Usurper' in an iron cage to fat Louis XVIII to whom, of course, he had sworn allegiance. After reading Napoleon's proclamation he took his first step to the firing squad, saying "That's how one speaks to soldiers!". One of Napoleon's best generals, Maximilien-Sebastien Foy, wrote " $A$ nos francais il faut toujours parler - avec les anglais jamais"; so perhaps
Wellington was right, and it is sad that many of his utterances had to be of 'The Commander-in-Chief notes with regret' variety. One of these did him immeasurable harm with his army, and in England when it was 'leaked to the Press' as we say today. This was the severe memorandum to commanding officers after the disastrous and mismanaged retreat from Burgos.

The two men were of course utterly different in background, character - everything. Wellington, a born aristocrat, took absolutely no interest in his own advancement. When he was made a viscount after Talavera, he left the choice of the title by which he was to become known to the World to a younger brother, William; and after Salamanca he exclaimed "What's the use of making me a marquess?" He would have preferred money to pay his troops, or siege equipment which would have helped him to be more sparing of their lives.

Bonaparte - Buonaparte - a member of the minor Corsican nobility, more Italian than French and hating to be reminded of it, exorcised a feeling of socias inferiority by making himself an emperor and creating hereditary nobility from his family and supporters. "We nobles", he loved to say; and, a crowning impertinence called the murdered Louis XVI "My poor uncle". Apar\$ from relatives, only Marshals Lannes and Duroc could tutoyer the Emperor; but with his junior officers and soldiers he was Democracy personified. Poor trusting victims, no one had told them that he had said "Soldiers are made to be killed"; and, even more chilling, "I cax afford to expend a hundred thousand men a year", ক্ truly foul saying not to be paralleled until Mussolini told Badoglio that he needed only a few thousand dead to ensure that he had the right to sit at the peace table in the capacity of a co-belligerent. Napoleon's old grognards, his vieux moustaches, should have listened to Kléber, called by Napoleon one of his two best generals. Kléber disliked:Napoleon and said that he was "the kind of general who needs a monthly dividend of ten thousand men".

Of course wars and battles would never be won if generals could not steel themselves to the melancholy need to accept the risk of inevitable casualties. "He who cannot look on a battle dry-eyed allows men to be killed needlessly" said Napoleon. To this dictum Wellington was a shining exception; but, surely even if we accept Napoleon's maxim, we can never condone an unfeeling, callous attitudes toward those who have paid the price of victory.

Tolstoi, in War and Peace mentioned Napoleon's well-documented fascination for viewing the corpses of men who had died doing his bidding. His own macabre boast was "With the last drop of blood gushing from their veins they cried Vive l'Empereur". On the hideous field of Eylau their loving father turned over with his foot the bodies of his soldiers remarking "Small change! 
Small change! A night of Paris will soon adjust all these losses". In 1812 his famous - I would call it infamous 29 th Bulletin, announcing the loss of nearly half a million men ended with the bland assurance that the Emperor's health had never been better. "Families dry your eyes, Napoleon is well" said Chateaubriand. During that terrible retreat, as he watched his men struggling and drowning among the ice-floes of the Beresina, all their Emperor could find to say was "Voyez ces crapauds!". Our soldiers called the French "Johnny Crappos" half affectionately; but today we settle for frogs - not toads. Wrapped in his furs in his sleigh, preparing to abandon his army for the second time, ${ }^{*}$ the Emperor was thinking only of himself and his reputation. "The Bourbons will make much of this", he lamented. By 1813 he was past attempting to conceal his ruthless ambition, lost his temper with Metternich in that famous interview in the Marcolini Palace in Dresden and shouted that the lives of a million men were nothing to him - actually, according to Metternich, he used a very coarse expression, as he often did when under stress. For example, at Waterloo when Ney begged for reinforcements, Napoleon said "Does he think I can — troops?", using a word with which I never care to defile the printed page. So, Napoleon loved his men?, believe that if you can. Can you believe that Wellington loved his? I can and I do.

Perhaps you sometimes wish that you could be present at some great moment in the past. How I would love to 'listen in' at one of Schubertiads! But in our military history my moment would be in a public park in Brussels just after Napoleon's escape from Elba. The little gossipwriter, Creevey, asked Wellington if he and Blúcher could do the business. A private soldier in his red coat was gazing at the statues and, pointing at him, Wellington said "It all depends on that article, give me enough of it and I'm sure". My respected former divisional commander, Sir Horatius Murray, with whom I debated verbally and in an exchange of essays, held that the words "that article" were spoken in a cold calculating, logistical manner. For me this great tribute to the British Infantry was spoken in warm human tones. Sir Horatius, a formidable historian, might be reminded that our most esteemed military historian, Sir John Fortescue, wrote that Wellington "had actually an emotional nature which he kept, owing to early training, under so stern control as to forbid it any vent except upon rare occasions".

Perhaps I should not make too much of the contrast between Napoleon's ruthlessness and Wellington's reputation as 'more sparing of his men's lives than any great general in history'. Napoleon could, and did bleed a great nation dry; but when Wellington, in the Peninsula, said "As this is the last army England has got *The first occasion was in Egypt in August 1799. Kléber, left to pick up the pieces, was assassinated in June 1800. we must take care of it", he had been told by Canning that there was 'no more in the kitty'. Like Jellicoe at Jutland, Wellington alone could have lost the war in a $\bigcirc$ day. How often he denied himself the satisfaction of following up his victories, only to be accused of excessive caution, as Montgomery was to be accused. Did the $\overrightarrow{\bar{s}}$ soldiers whose lives were spared deride caution as ao failing in their generals?*

Wellington's care of his men began at an early age $-\frac{\overline{\bar{D}}}{\bar{D}}$ an astonishingly early age for those days when, despite $\mathbb{Q}$ General Wolfe's 'Instructions for Young Officers' published in 1758, I doubt if 'Man Management' as we began to call it during the Second World War, was ever? deliberately taught to young officers. When an ensign in $\overrightarrow{ }$ the 73rd Highland Regiment, and not yet 18 , he is said ${ }^{\omega}$ to have weighed one of his soldiers in his clothes alone and then in full kit and equipment, "in order to compare $\exists$ the power of the man with the duty expected of him". It ? took the brains of the Army Hygiene Department over a $\vec{\omega}$ hundred years to correlate the soldier's body weight with $\vec{\circ}$ his load. Wellington himself, in old age, brushed off questions about this piece of enlightened research, $N$ saying that he had not been too young to realise that as he had undertaken a profession he had better learn aㄱ $\rightarrow$ about it. Some doubts surround this episode in the Wellington Legend. Fortescue thought that it probaby happened when he was in the 58th Regiment, when would have been about 22 - still not too bad for LaAy Mornington's "awkward son ... food for powder amd nothing more". Doubt has also been expressed about noy favourite story (or is it legend?) about the origin of the name 'Thomas Atkins'. I am sure you know it. It was at Boxtel that the 25 year old Arthur Wesley (the family name had not yet been changed to Wellesley) commanding the 33rd Regiment, first saw men under his $\underset{\Omega}{\stackrel{\Omega}{\Omega}}$ command killed and wounded - and he took it very hard. $\overrightarrow{\vec{F}}$ A young soldier with a mortal wound looked up into the $\frac{?}{3}$ grief-stricken face of his young $\mathrm{CO}$ and sought to? comfort him. Said Private Thomas Atkins, for that was? really his name, "It's all right Sir - it's all in the day's work" and died. In 1843, a time when The Duke - there was really only one in England - was consulted about everything ("Try sparrow hawks Ma'am" - and all that) a staff officer was sent to Walmer Castle to get his advice about nothing more earth-shaking than a suitable name $\frac{\overline{\vec{F}}}{\bar{F}}$ to put on a sample Army form, to help ill-educated soldiers to complete it. Should it be 'I, John Smith, Jones? or Robinson?'. Better ask the old Duke. His thoughts $ᄋ$ slipped past Waterloo, Salamanca, Assaye, perhaps his $₹$ *In St Helena Napoleon said that he considered that $\stackrel{\circ}{\triangle}$ Wellington had been as good a general as himself, except $\rightarrow$ for the fault of excessive caution. Before Waterloo he had often said that Wellington was a bad general, and he has $N$ been credited with the epithet, 'The Sepoy General'" though, to me, this sounds more like a jealous tongue in 0 The Horse Guards. 
three greatest victories, to Boxtel, where he had said he at least had learned what one ought not to do. "Thomas Atkins", he ruled decisively. Now I know that a tiresomely accurate historian, none other than a former Director General, Sir William MacArthur, pointed out that the name Thomas Atkins had been used at least a hundred years earlier as a generic term for the British soldier. But Sir Percy Scholes once wrote; "You cannot kill a really bold, detailed and romantic lie"; and I for one cling to the legend because it fits the Wellington I like to think of - the awkward son who kept his emotions under stern control; the young officer who burned his violin and decided to learn all he could about soldiering; the young $\mathrm{CO}$ and the middle-aged general who wept for his men's sacrifices; the senior commander who disliked saying unkind things about anyone, even when he ought to have done so, in confidential reports on thoroughly worthless officers, as the Duke of York sternly told him;* the Iron Duke - iron in everything which touched his duty to his sovereign but in human relations the iron was more malleable than most men suspected; the great soldier who did not dare to let his men see his human side too often; the grand old man who never forgot his first Thomas Atkins.

This is not partisan rhetoric, it is all true, or so I believe. When Sir John Fortescue wrote: "Three times only in the course of his long life did men see the Iron Duke give way to tears", he was, I believe, understating the facts ${ }^{8}$. There are many contemporary accounts of Wellington's grief and tears over the casualties and the loss of friends. Far from gloating, like Napoleon, Wellington said (to Lady Shelley) "Next to a battle lost the greatest misery is a battle gained". "No, do not congratulate me, I have lost all my best friends" he cried bitterly after Waterloo. It was not only for friends that he wept. He lost no special friend at Badajoz. His outburst of weeping was for the sacrifice of his soldiers. When casualty reports began to come in Dr McGrigor saw his ghastly face in the glare of a torch and later wrote, "I shall never forget it to the last moment of my existence" : Later when Wellington saw the dead piled up on the glacis he broke down completely and, when the bitterness of his weeping embarassed the tough Sir Thomas Picton, Wellington camouflaged his feelings by cursing the Government for failing to provide the siege train which would have saved him from demanding such unparalleled sacrifices from his men. ${ }^{* *}$

\footnotetext{
${ }^{*}$ He once told one of his many lady friends how another of them had said to him almost petulantly - "Do pray abuse somebody - but she did not prevail".
** Years later Wellington told Mrs Arbuthnot how he had broken down and tried hard to conceal it, "I bit my lips and did everything I could to stop myself'. See The Great Duke by Sir Arthur Bryant 1971; $p 313$.

As I have said, contemporary memoirs and diaries $\stackrel{\curvearrowright}{\circledR}$ abound in illustrations of Wellington's true feelings; but $\bigcirc$ of course proving that he truly cared for his men, whilst $\frac{\text { 응 }}{2}$ to Napoleon his were mere tools of his lust for power, $\stackrel{\oplus}{?}$ but does not really tell us enough about their attitude to $\overrightarrow{\overrightarrow{\mathrm{S}}}$ their Medical Services. After all tools must be kept in $\vec{\sigma}$ good repair, mended and returned for further use; and in this respect Napoleon was certainly served by fine $\frac{\bar{\sigma}}{\omega}$ surgeons.

One of Wellington's soldiers blamed what he believed to be a shortage of good surgeons in our Peninsular army os on the Anatomy Act, writing that the French benefitted $\vec{O}$ from "the superior opportunity they have of studying $\overrightarrow{-}$ anatomy which in Britain is now almost prohibited - $\omega$ more the pity". This exceptionally percipient young soldier was Joseph Donaldson of the 94th Regiment ${ }^{10}$.

No doubt Dr McGrigor found scope for reform, for he was not easily pleased; but I think we can certainly $\vec{\omega}$ believe his claim that by the end of the Peninsular War $\overrightarrow{0}$ he had "a body of operators such as never was excelled, $\frac{\overrightarrow{1}}{\dot{ }}$ if ever before equalled"; and that the medical men in the Army were among the best in the profession.

Sir John Fortescue had this to say about Napoleon's record: "In spite of many effusive orders and utterance Napoleon took no care of his soldiers. He did not p\&y them; he did not feed them; he did not clothe them; if made no sufficient provision for the sick and woundes and his hospitals were a disgrace to his name"11. $\vec{\varphi}$ German observer of Napoleon's grossly inadequafe of medical arrangements at the Battle of Leipz䅉 concluded: "the soldier who has been crippled in actio and can fight no more is nowhere held in such low esteem as in the French Army"12.

How then did opinions such as those of Joseph $\frac{\circ}{8}$ Donaldson take such firm root in the Napoleonic Legend, to the detriment of the reputation of our own 0 medical services? Almost entirely from the reputation $\frac{3}{5}$ of Dominique Jean Larrey, described in Napoleon's will as "the most virtuous man I have known". Larrey" deserves our respect as a great military surgeon, and as the father of the field ambulance and of what I liked to call 'close forward medical support of troops in the field'; for his ambulances volantes were not just special $\mathbb{\Phi}$ vehicles, they were fine medical units. But I cannot $\frac{\stackrel{\rho}{F}}{5}$ admire him as a man. His biographers, especially the most idolatrous of them all, André Soubiran, did Larrey a disservice by publishing so much of his own $\delta$ correspondence, full of self praise, complaints about 3 those who had obstructed his ambitious career (mostly 0 physicians); open solicitation for honours and awards; and - worst of all - constant grumbling about the inadequacy of the rewards given to him by senior officers whose lives he had saved. His latest English biographer, $O$ Dr Robert Richardson, relates without apparent $N$ disapproval, the story of Larrey returning a diamond $\underset{\omega}{N}$ given to him by a general, after having it valued and 
finding it only worth five louis. To an Army doctor it is nauseating to see this great military surgeon, 'The Soldier's Friend' as he deserved to be called, in the rôle of a medical mendicant. Larrey was a sycophant, a 'yesman', never one of the very few bold doctors who dared to oppose Napoleon. The most important of these to the Army was Desgenettes (René-Nicolas Dufriche, Baron Desgenettes) whose refusal to co-operate with Bonaparte in 1799, over the poisoning of French soldiers suffering from plague, cost him his appointment as Principal Medical Officer of the Army, leaving the field clear for Larrey, who kept quiet and received a ceremonial sword. Bonaparte justified his treatment of plague as 'mercy-killing' (in the modern jargon), but we Army doctors should surely feel proud of Desgenettes who said that his mission was to save life not to destroy it. The real indictment of Bonaparte* is that he deliberately chose to abandon wounded men along the line of his retreat and poison the sick, rather than allow his failure to be seen for what it was in the eyes of the world, and especially in France, by accepting Admiral Sir Sidney Smith's offer of safe-conduct and the evacuation of French casualties in British vessels. Desgenettes - no 'yes-man' as he was to prove again in Russia in 1812 - made contributions to Military Medicine just as important as those of Larrey; being a pioneer in military hygiene and in the organisation of the great military hospital of Val de Grace. ${ }^{* *}$

The really important thing to remember about Larrey is that his splendid services - 'flying ambulances' and all - were provided exclusively for the Imperial Guard. The rest of the army, as we have seen, suffered terribly. The chief pharmacist to the Grande Armée during the Austrian campaign of 1809 , Charles-Louis Cadet de Gassicourt, wrote that "three days after a battle under the walls of Vienna the wounded were still left on the battlefield, except for the Imperial Guard whom the brave Larrey would never abandon"13.

Larrey busied himself being 'virtuous' under the eyes of the Imperial fount of honour. What a contrast this boastful, grasping Gascon presents to the great Aberdonian whose statue stands in our garden here at Millbank.

Dr McGrigor soon got Wellington to see him personally every day instead of receiving the medical reports from the Adjutant General, and later persuaded him to mention, for the first time, the doctors in his despatches - it was after Badajoz - but he cared little

\footnotetext{
* Apart from a foretaste of his ruthlessness - the hideous massacre of over 4,000 Turkish prisoners-of-war at Jaffa - bayonets being used, on Bonaparte's orders, to save ammunition. See Bonaparte in Egypt, C Herold 1962; pp 274-277.

** Sir John Fortescue credits Sir James McGrigor with being "the father of military hygiene". Wellington $p 215$.
}

about his own advancement. When Wellington recommended McGrigor for a knightood he described $\Omega$ him as "one of the most industrious, able and successful 음 public servants I have ever met with"; and promised to present his old friend Mac at the levée. Unavoidably $\vec{\Rightarrow}$ prevented from doing so, he arranged for Lord Bathurst $\stackrel{0}{+}$ to act as sponsor and hastened to London to introduce McGrigor to him, saying "You are such a shy fellow and $\frac{\bar{O}}{\overline{0}}$ might not have found him out". McGrigor cited this as $\frac{\widehat{\sigma}}{\bar{\phi}}$ an example of the Duke's "benevolence of character ... ¿ which those only who had been much near him could क know". "A shy fellow" - very unlike the pushful Baron $\vec{\circ}$ Larrey. When Sir James wanted to retire at the age of 75 Wellington said "No, no Mac, there's plenty of work in $\vec{\omega}$ you yet". One wonders what the promotion-hungry Inspectors General thought of that.

Any military reader can see in Sir James' Autobiography a picture of a perfect relationship between a commander and his medical adviser.* Such a relationship, essential to the well-being of a unit or formation, must be one of mutual trust and give and take. The doctor can often provide a sympathetic ear fơ his commander's anxieties, owing as he does his first allegiance to the profession of medicine; and being ofte $\bar{B}$ nearer in age to the commander than other members of the staff - McGrigor was three years younger that Wellington. The doctor should never be too obstinate to accept guidance in matters touching his secont profession - that of arms, whilst, unobtrusively 18 necessary, guiding his commander in matters touching his first. In this respect McGrigor's commander had (⿳⺈⿴囗十⺝⿱ willing ear. Whilst commanding the 33rd Foot, Colonet Wesley (not to become Wellesley for about a year) wrote to the Governor General of India a very long letter expounding the need for the commanding officer and his medical officer to act as a team in promoting the health and welfare of the soldier. This letter, which expresses in the language of his day, the views of truly enlightened commanders of today, was called by an American historian, Dr I. S. Ravdin, "the greatest military medical letter ever written by a great field commander" ${ }^{14}$. Our great field commander was 28 years old when he wrote it.

The chief lesson which McGrigor had to learn was that nothing must take precedence over the attainment of the military objective. Without that, all our plans for the casualties could come to naught; and, of course, many more casualties could result. I was once present when a very senior Territorial medical officer, every bit as famous as 'Mitch', forgot this lesson and paid for it ${ }^{15}$.

It would be very wrong to suppose that Wellington brushed aside McGrigor's requests for ambulance ${ }^{*}$ As a picture of life at Wellington's headquarters it is a worthy companion to the better-known Private Journal of Francis Seymour Larpent, the Judge Advocate General. McGrigor became a baronet in 1824. 
transport, a better regimental medical establishment and so on. He thought them over and some days later told McGrigor that his ideas were excellent if they had been practicable; but said "I cannot risk encumbering the army or impeding its movement either in advancing or retreating". He always found time to discuss medical matters and even when pre-occupied with the planning of the Battle of Vitoria, he wrote a very long letter on the subject. A good example of his methods, when he could help, is his reaction to McGrigor's idea of prefabricated hospital huts. The credit for introducing these into our army is sometimes given to Florence Nightingale, but properly belongs to McGrigor. When he made his proposal to Wellington he thought that "he did not appear to pay much attention to the suggestion"; but not long after, at his usual morning visit, Wellington said "By the bye, your hospitals are ordered out and may soon be expected". He had arranged it all himself and, with his usual practical commonsense, had asked for carpenters to be sent out to instruct and supervise in the erection of the huts. $\mathrm{He}$ added drily that he expected "they will be a vast expense to the country".

Sir John Fortescue tells us that "the only spring waggons of the army - those of the Royal Waggon Train - though intended for general transport work, were exclusively for the sick and wounded men and were the germ of the modern ambulance". Nevertheless it was for his very own ambulances that McGrigor hankered. At the end of the Peninsular War, after a tour of inspection of French medical arrangements, he concluded that we had "very little to copy from them", except for special ambulances for Fortescue's sick and wounded men. He added that, when Wellington had felt unable to agree to this, he would not "give the credit of humanity to Napoleon as the motive of his introduction of it into his army". Surely we, who now know so much more than even Wellington could have known about Napoleon's fundamental inhumanity, must agree with the Duke. After all, an imperial edict - that cliché, a stroke of the pen, could have swept away the obstructions of 'The Administration', of which Larrey continually complained, and reformed the medical services of the whole French Army; whereas for Wellington the need to plead for the barest necessities of campaigning from a suspicious, parsimonious and often positively hostile government was a frustrating addition to the daily anxiety and burden of high command. Can we wonder that he was occasionally ill-tempered?

This brings me to my personal theory, which I first expressed in writing in $1962^{16}$, to account for his conduct on that celebrated occasion when McGrigor received a much publicised and well-merited 'rocket'. Well merited? He had as we might put it today, evacuated his casualties on his own initiative and without informing Wellington, by a route other than the main administrative axis. Wellington, you will remember, was sitting to Goya for the well-known portrait and worked himself up into such a towering temper that Goya fled $\stackrel{\varrho}{\Omega}$ from the room - fled too soon to see the fiery young 0 general calm down and quietly invite the doctor to supper that evening when, McGrigor tells us, the Duke showed him "unusual civility and marked attention". Remember that Wellington was only 43 at the time, 0 bearing the anxieties of a difficult campaign almost $\bar{\sigma}$ alone, for he kept his plans closely, perhaps too closely, $\frac{\bar{s}}{\square}$ to himself. All this was enough to account for his rage; $\mathbb{\mathbb { Q }}$ but I suspect there was more to it. Have a look at that portrait and suppose that Wellington had caught $a_{\vec{A}}$ glimpse of how it was shaping. What did he see? Well, $?$ for a start there was a hint of the blue chin about which $\overrightarrow{\vec{\omega}}$ he was so sensitive that he used to shave three times a $\stackrel{\omega}{\omega}$ day, even in the field and with those ghastly implements which we can see in Apsley House. His nicknames 'Beau 3 Douro' or 'The Beau' suggest that he was, if not vain, at? least concerned about his personal appearance. But it is $\vec{\omega}$ a known historical fact that Wellington disliked that portrait and I believe that he did so for a stronger reasor. $\vec{P}$ Like Sir Thomas Lawrence's earlier portraits, ${ }^{*}$ it shoves $N$ him as a proud, haughty, even cold aristocrat - just as 을 millions can see him today on our $£ 5$ note. He knew th this was how most men saw him. He also knew that the was not his true nature. Did he sometimes wish that ife possessed the warm human appeal which made Napoleon, in Wellington's own words, "worth reinforcement of 40,000 men by his mere presence onga $\infty$ battlefield"?

I have offered you my personal theory about Wellington's furious rebuke of Dr McGrigor because] am sure that it has been the chief source of the myth the damned lie - that Wellington did not support his doctors.

Now, I have spent far too long in what I expect and $\vec{F}$ hope, has been 'preaching to the converted'. I have $\frac{O}{3}$ focused attention on certain facets in the characters of $\overrightarrow{ }$ these two fascinating national heroes. But surely no advocacy of mine was needed to convince you that Sir Arthur Bryant was right to call Wellington 'England's Greatest Son'. Yes, England's! Brush aside those 뽈 Irishmen, with whom our Corps was overpopulated in my young days. Why I have even heard them claim for Ireland our beloved John Moore - son of a Glasgow doctor* and the Glasgow High School's greatest F P' as we call them in Scotland - well some of us do. If they * Lawrence's portrait of Wellington in 1824 shows $a$ ᄋ mellower Duke; but for me the portraits by Thomas Heaphy (1813) and Thomas Phillips (1814), especially the latter, bring him to life, as he surely must have looked, $\frac{D}{2}$ as a young general in the Peninsula.

** Dr John Moore, born in Stirling, served in the Army, N as surgeon's mate with the Duke of Argyll's Regiment at ${ }_{N}$ Maastricht; and also in the Netherlands, with the N Coldstream Guards. 
refuse to be brushed aside remind them that the Duke himself said "Being born in a stable does not make a man a hoorse".

As for Napoleon, no character in history has been more shrouded in a veil of false beliefs and claims, mostly created and fostered by himself and his worshippers. Even when he was our Nation's greatest enemy his worshippers included thousands of Englishmen - notably in the Parliamentary Opposition - the Whigs and especially Charles James Fox. The man was a megalomaniac dictator, forerunner of a grim succession of modern dictators, admittedly becoming even more horrible. If you think that my obvious adoration of Wellington has led me to unbalanced detestation of Napoleon, let me tell you that for at least three decades French authors have been taking a very critical look at the Napoleonic Legend and finding many flaws. Anything which I have said or written is mild compared to the vituperation of such as Henri Guillemin, who cannot find a single redeeming feature in this brigand chief of a rapacious Corsican clan ${ }^{18 *}$.

But, a last word about their medical services. It would be wrong to minimise the dreadful sufferings of our wounded men in the Peninsula, however hard McGrigor and his doctors tried to alleviate them. Through every contemporary memoir there resounds the ghastly squealing and groaning of the bullock carts, with what felt like square wheels. When their cargo was wounded men it was not only the ungreased axles which groaned. But the French were no better off, worse indeed, for ${ }^{*}$ In Hugh Kingsmill's opinion (Ingrams R. God's Apology 1977; $p$ 170) 'The epitaph of the nineteenth century should be "It admired Napoleon". Not all of them did. An American poet, Joel Barlow (1754-1812) ended his poem about Napoleon 'Advice to a Raven in Russia', with these lines: "Hurl from his blood-built throne this king of woes - Dash him to dust and let the world repose". Oxford Book of War Poetry 1984; 8 86. they faced horrid mutilation and death at the hands of savage Spanish peasants who, of course, had countless? similar atrocities to avenge, as Goya helps to remind us. $ᄋ$

All I ask is that you will join me, whenever theo occasion offers, in denouncing the lies and false beliefs." of which I have spoken, which tarnish the reputation of our greatest general and of his medical services, which believe, despite their obvious limitations, were worthy들 forerunners of the Service to which we - like Philip⿳亠丷厂 Mitchiner - have been devoted and of which you, Sirळ Alan are proud to stand at the head.

\section{REFERENCES}

1. Gray, T C. Another side of Mars. J R Army Med Corps $\overrightarrow{\vec{\omega}}$ 1984; 130: 3-11.

2. ANTOMMARCHI, F. The Last Days of the Emperor Napoleon. Vol II; 1825: 162-163.

3. Mulmall, M G. Dictionary of Statistics; 1891.

4. RichardSON, F M. Napoleon. Bisexual Emperor; 1972.

5. Richardson, F M. Mars without Venus; 1981: p 105-107. $\vec{\omega}$

6. FoY, M S. Histoire de la Guerre de la Péninsule sous Napoléon; 1828.

7. FORTESCUE, J. Wellington; 1925.

8. FORTESCUE, J. History of the British Army Vol VIE; 1917: p580.

9. MCGRIGOR, J, Autobiography and Services; 1861: p 273.0

10. Donaldoson, J. The War in the Peninsula; 1825.

11. ForTESCUE, J. History of the British Army Vol VIfin 1917: p 11.

12. BRETT-JAMES, A. Christian Ludwig Hassall, quoted 'Europe against Napoleon'; 1818.

13. DE GAssicourT, C L. Cadet. Voyage en Autriche, Moravie et en Baviére, pendant la campagne de 1809.

14. RAVDIN, I S. Some problems facing Military Medicin Lecture at the Naval Medical School, USA; 25.9.195 (sent to me by General William J Kennard, United Statg Army Medical Corps.

15. RichaRdSON, F M. Care of the wounded - Letters to the Editor. J R Army Med Corps 1975; 121: 164-165.

16. RICHARDSON, F M. That Goya. Army Quarterly; October 1962.

17. BRYANT, A. The Great Duke; 1971.

18. Guillemin.H. Napoléon tel quel; 1969.

\section{RAMC JEWELLED BADGE BROOCHES}

From time to time Regimental Headquarters is asked to inform officers if and when a brooch becomes available. A list of those interested is maintained at RHQ. Readers who wish to acquire a quality brooch, of either classical or more modern style, are advised that Paul Longmire Limited, 12 Bury Street, St James's, London SW1 are well known to RHQ and are a recommended source.

The firm offers regimental brooches from stock or to customers' requirements, has the occasional used brooch and also has a unique range of enamelled and engraved gold cuff-links.

Readers may be assured of Mr Longmire's personal attention by telephoning $01-930-8720$ or by writing to 12 , Bury Street. 